\title{
Development of MojiGoiGo!: Adobe Flash Based Learning Media For JLPT Preparation
}

\author{
Kadek Eva Krishna Adnyani \\ Japanese Language Education Department, Ganesha University of Education, Singaraja \\ Email: krishna.adnyani@undiksha.ac.id \\ Gede Satya Hermawan \\ Japanese Language Education Department, Ganesha University of Education, Singaraja \\ Email: satya.hermawan@undiksha.ac.id \\ I Gede Partha Sindu \\ Informatics Education Department, Ganesha University of Education, Singaraja \\ Email: partha.sindu@undiksha.ac.id \\ Ni Made Yunita Dewi \\ Japanese Language Education Department, Ganesha University of Education, Singaraja \\ Email: mystical.yunita@gmail.com
}

\begin{abstract}
This study aims to develop Adobe Flash CS6 "MojiGoiGo!" Based Learning Media for Preparation of Level 4 Japanese Language Proficiency Test (JLPT) for Second Semester Students of the Japanese Language Education Department Ganesha University of Education. This research and development uses the development model of Hannafin and Peck. The data are collected through literature review and questionnaires. The collected data are then analyzed by using quantitative analysis. On the requirement needs assess phase, questioners are given to 32 students of second semester of Japanese Language Education Department. On the design phase, materials and products are designed and then inputted into software. On the develop/implement phase, validation of the content and media experts, individual tests, and group trials are conducted. The results of experts validation and individual trials show that the media are considered excellent, while group trials gave judgment on the category of good and excellent.
\end{abstract}

Keywords: research and development, learning media, adobe flash CS6, Japanese-language proficiency test

\section{INTRODUCTION}

The development of multimedia-based learning media in Indonesia is still needed by the students because of the lack of appropriate learning media. Some of the obstacles faced include psychological, educational, social, economic and legal aspects (software piracy is still ongoing), and in terms of infrastructure. The main problem is the difficulty of developing multimedia-based learning media such as the very limited human resources to develop software. In addition, the utilization of computer in Indonesia, especially at schools, is still at merely for typing or administrative purposes. So the idea of the importance of computer education development has not received adequate response (Wijaya, 2011).

In the world of education today when the competition level to get to the international level is so tight, many educational institutions provide learning for foreign languages, one of which is Japanese language. One of the institutions that provide Japanese language learning is the Japanese Language 
Education Department of UNDIKSHA that runs on the field of Japanese language education whose outputs are Japanese language teachers.

In order to know the students' level of Japanese language proficiency, they are encouraged to take the Japanese language proficiency test called Nouryoku Shiken.or JLPT (The Japanese-Language Proficiency Test). The result of this test is very necessary for those who want to find a job since some Japanese companies in Indonesia do recruitment and have a payroll system based on the test result. The Nouryoku Shiken is considered to be able to measure one's Japanese language proficiency.

On the official website of JLPT (2012), it is mentioned that The Japanese-Language Proficiency Test (JLPT) under joint organization of the Japan Foundation and Japan Educational Exchanges and Services (previously Association of International Education, Japan) started in 1984 as a test to measure and certify the Japanese-language proficiency of those whose native language is not Japanese. In the first year the JLPT was conducted in 15 countries, and approximately 7,000 examinees took the test. Since then, the JLPT has become the largest Japanese-language test in the world, with approximately 610,000 examinees in 62 countries and areas worldwide in 2011. This success is entirely due to the support and cooperation of all involved.

In JLPT there are Four Key Characteristics, namely:

1.1 Point 1: Measures communicative competence required to perform tasks

1.2 Point 2: Select a suitable level from among five levels

1.3 Point 3: More accurately measures Japanese-language proficiency with scaled scores

1.4 Point 4: "JLPT Can-do Self-Evaluation List" is offered

Based on the results of the questionnaire, it is known that the second semester students of the Japanese Language Education Department of the Ganesha University generally begin to follow JLPT at level 4 (known as N4) which contains a summary of linguistic competence as follows:

The ability to understand basic Japanese.

A. Reading

One is able to read and understand passages on familiar daily topics written in basic vocabulary and kanji.

B. Listening

One is able to listen and comprehend conversations encountered in daily life and generally follow their contents, provided that they are spoken slowly.

JLPT not only emphasizes (1) the knowledge of Japanese vocabulary and grammar, but also (2) the ability to use that knowledge in real communication. Therefore, JLPT measures Japanese competency through 3 elements: Goji Moji Test (letters and vocabulary) to measure point (1), the Dokkai Test (reading), and Choukai Test (listening) to measure point (2).

Based on the preliminary study questionnaires that have been distributed, it is known that $100 \%$ of students of the second semester of the Japanese Language Education Department of the Ganesha Education University give the answer that they need learning media as the preparation before taking the JLPT 4. Furthermore, when asked more details about the media in the form of what flash media the desired, $73 \%$ of students want a mobile-based flash media and as many as $100 \%$ of students who want a mobile-based flash using smart phones with Android operating system. When asked about the most difficult part of the three elements of questions in JLPT, 59\% of the students answer that the most difficult part is the moji goi (letters and vocabulary). The results of this questionnaire show that the development of online-based media that is practical and can be accessed anytime and anywhere, is needed by students.

This is in accordance with a statement from Pratomo and Irawan (2015) that online-based learning media can help enhance learning outcomes achieved by learners. Online-based learning media will also motivate students to learn independently, creatively, effectively, and efficiently. In addition, it is expected to reduce students' boredom. Susilana and Riyana (2009) also put forward the limitations of space, time, energy, and sensory power, create a passion for learning, and allow students to learn independently. In its use, learning media must be relevant to the competence to be achieved and the content of the learning itself.

Based on the needs analysis, research on media development with focus on learning moji goi (letters and vocabulary) is important to do. The learning media developed are flash based and named 
"MojiGoiGo!". The selection of online application form in the development of learning media has also been based on needs analysis.

As mentioned by Nunes and Fowell (in McPherson and Nunes, 2004: 60), An online learning application is specifically produced to address a particular educational need, and is thus limited to solution of the problems arising from that need. Hopefully, the use of this technology in the learning process can facilitate learners to prepare for the Japanese language skills level 4 test, so that the passing rate of students to the test can increase. Previously, research on application development for JLPT learning has been done previously by Chandra et al (2017) and Carqua and Berutu (2015). However, Chandra et al's research focused on vocabulary learning (no exercise questions) and is intended for preparation of JLPT level 3 tests. Carqua and Berutu research is focused on learning materials and questions but for preparation of JLPT level 5. So, it is expected that this research can complement these previous researches.

In line with the background previously described, it can be formulated as follows:

1. What is the form of Flash-Based Learning Media "MojiGoiGo!" for the preparation for the Japanese Language Proficiency Level $4 \mathrm{P}$ used by the Second Semester Students of the Japanese Education Department Ganesha University of Education?

\section{METHODS}

This research uses descriptive quantitative analysis. The development model used in the development of image media is the development model of Hannafin and Peck. In this research, the data collection used techniques of document recording and questionnaires.

\section{FINDING AND DISCUSSION}

This research was developed with the development model of Hannafin and Peck. In the development model of Hannafin and Peck, there are 3 development phases, namely, the needs analysis phase, the design phase, the development and implementation phase. In the phase of requirement analysis questionnaires are given to second semester students of the Japanese Language Education Department. In the design phase, materials and products are designed, and then inputted into software. In the development and implementation phase, the validation of instructional media is done by 2 . Then, it is followed by individual test involving 3 students as well as small group trial involving 9 students ( 3 high ability, 3 medium ability, 3 low ability).

\section{Phase Needs Analysis}

At this stage, a questionnaire analysis of the needs of the second semester students of the Japanese Language Education Department of Ganesha Education University was conducted. 100\% of students stated that it is necessary to make N4 learning media. When asked more details about the media in the form of flash media as what is desired, $73 \%$ of students want a mobile-based flash media. All of students (100\%) who desire having a mobile-based flash are using smart phones with android operating system. The results of this questionnaire indicate that the students really want the products to be developed.

\section{Design Phase}

This product contains elements of moji-goi questions consisting of 5 types of questions that have been adapted to the standard test nouryoku shiken $\mathrm{N} 4$ ie もんだい1'mondai 1', もんだい2 'mondai 2', もんだい3 'mondai 3', もんだい 4 'mondai 4', もんだい 5 'mondai 5'. In もんだ ' 1 'mondai 1' the user is asked to select an answer option (hiragana letter) that corresponds to the underlined letter of the kanji on the question. Then in もんだい 2 'mondai 2 ' the user is asked to select an answer option (kanji) that matches the underlined hiragana letter on the question. In $九 た ゙$ い 3 'mondai 3' the user is asked to select the answer option (the most suitable word) to complete the sentence on the question. In もんだい 4 'mondai 4' the user is asked to choose an answer that the sentence meaning is the same / according to the question. In もんだい 5 'mondai 5 ' the user is asked to select the answer option (sentence) which is most appropriate for the vocabulary on the question. If 
the user selects the correct answer then the correct answer will appear. If the wrong user selects the answer option then the confirmation will appear wrong answer and correct answer. Here are the preview and features found on the app.

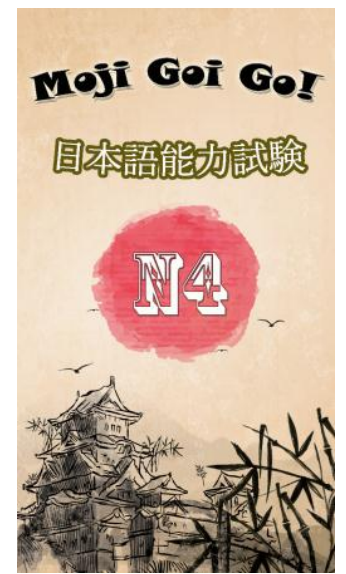

Figure 1. Preview of Figure

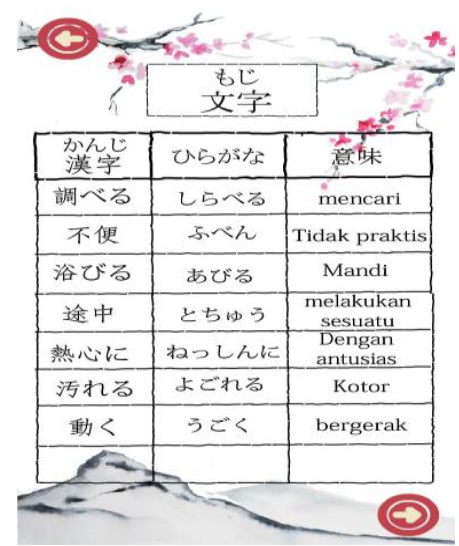

Figure 3. Display of Moji (letters) Material

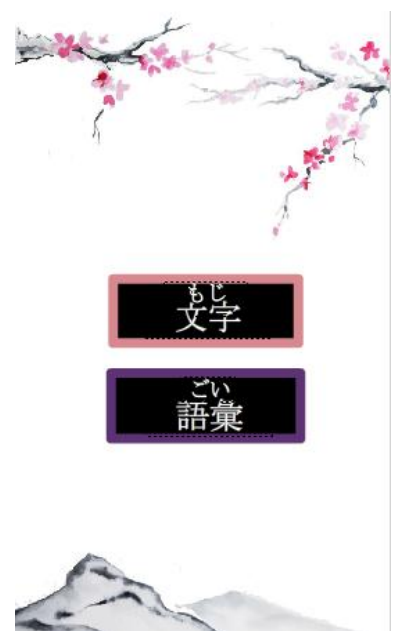

Figure 2. Material Display

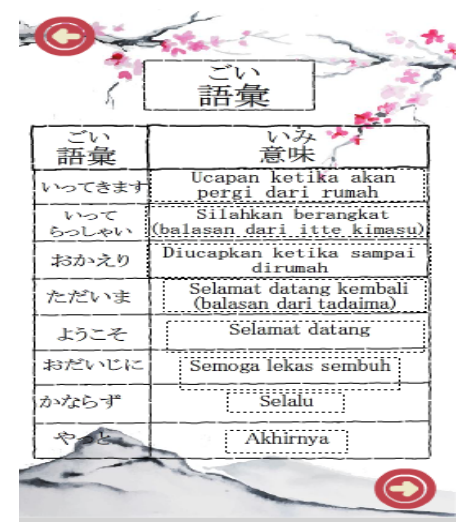

Figure 4. Display of Goi (vocabulary) Material

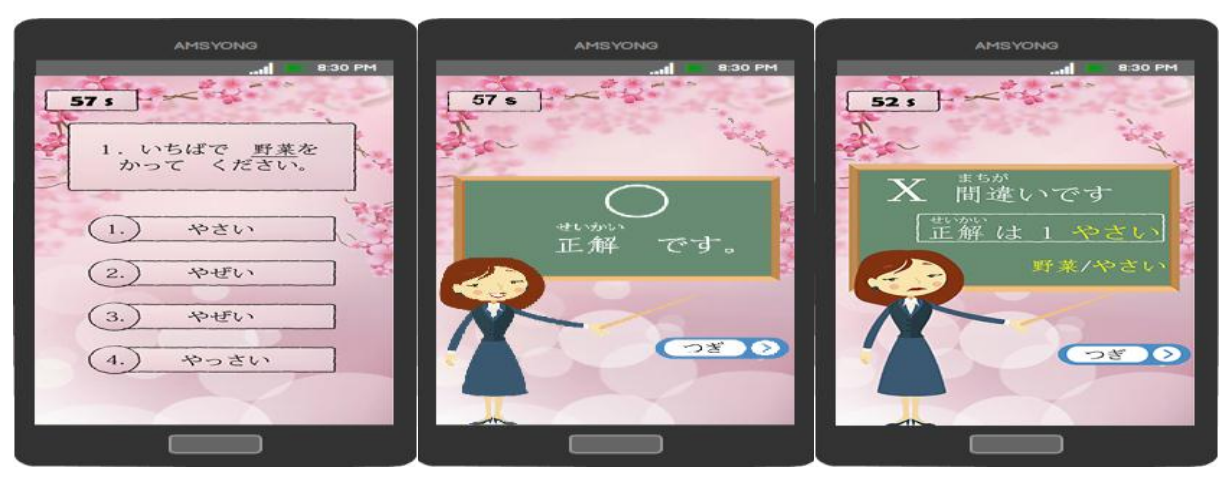

Figure 5. Display of Question Materials

If the user chooses the correct answer, a confirmation page (middle figure) will automatically appear confirming the correct answer with a caption in Japanese "Seikai desu" (true). Meanwhile, if the user chooses the wrong answer, then the confirmation page will appear confirming that the answer is wrong (right figure) with a caption "Machigai desu" (wrong) along with the correct answer. On the 
confirmation page of wrong answer there is also some the example of its correct use in a complete sentence.

\section{Phase of Development and Implementation}

The development and implementation phase is the last phase in the Hannafin and Peck's model. Validation of the learning media was conducted by two experts and then followed by individual test involving three students and small group trial involving nine students ( 3 high ability, 3 medium ability, 3 low ability). Feasibility test is done to know whether this product development has reached the target of learning as a means of practice for moji-goi (letters and vocabulary) for the preparation of Japanese language proficiency test level N4.

\section{Expert Test Results \\ 1. Media View}

a. The size of the letters (hiragana / katakana, kanji) used on the noryouku shiken $\mathrm{n} 4$ media with mobile based flash is appropriate. This point gets a score of 4 (Agree) and 5 (Strongly Agree)

b. Media design (background and animated characters) is attractive, so it can increase the motivation of users to practice: This point gets score 5 (Strongly Agree) and 4 (Agree).

c. The color composition of the writing and the background is appropriate: This point gets a score of 5 (Strongly Agree) and 4 (Agree).

d. The use of confirmation page (right or wrong) after clicking the answer button is appropriate. This point gets a score of 4 (Agree) and 5 (Strongly agree)

e. The instruction in Japanese and Indonesian language as well as sample questions given before starting the quiz really helps the user in answering the question: This point gets a score of 4 (Agree) and 5 (Strongly Agree)

f. The placement of Menu and buttons in media noryouku shiken N4 with mobile based flash is well organized.

Buttons and menus on this media are well placed. The start menu which is designed like a wooden board and the systematic placement of the menu from instructions, sound, source, and last practice are all appropriate. This point gets a score of 5 (Strongly Agree) and 4 (Agree)

g. The systematic presentation of the quiz complies with the standard N4 level Japanese language proficiency test for the moji-goi element (letters and vocabulary): This point obtains a score of 5 (Strongly Agree) from both experts

h. The time duration (timer) used to answer all the questions on the application is appropriate.

The time provided to answer 10 questions on this medium is adequate. The duration has also been adjusted to the degree of difficulty of different types of questions in each mondai. For mondai 1 and 2 the users have 10 seconds for each question (total 100 seconds). For mondai 3 the time given is 15 seconds for each question (total 150 seconds). For mondai 4 the time given is 20 seconds for each question (total 200 seconds) and the last one is mondai 5 with 25 seconds for each question (total 250 seconds). This point gets a score of 4 (Appropriate) from both experts.

\section{Exercise Media Content}

a. The use of kanji / hiragana for vocabulary is appropriate and in accordance with Japanese language level standard level N4: This point gets a score of 5 (Strongly Agree) from both experts.

b. The use of backsound in noryouku shiken $\mathrm{n} 4$ media with mobile-based flash increases the user's motivation to answer the question: This point gets a score of 4 (Agree) and 5 (Strongly Agree).

\section{Exercise Media Efficiency}

a. Instruction buttons and quiz hints on the media really help the users in running the application: This point gets a score of 5 (Strongly Agree) and 4 (Agree).

b. This media can help students' memory especially on moji-goi element (letters and vocabulary): This point gets a score of 4 (Agree) from both experts. 


\section{Exercise Media Quality}

a. The media is attractive, so it can increase the users' motivation to practice on Japanese letters and vocabulary: This point gets a score of 5 (Strongly Agree) from both experts.

b. The questions in this media are original: This point gets a score of 5 (Strongly Agree) and 4 (Agree).

The results of expert assessment are calculated and then converted by using the following formula.

Table 1. Conversion Formulas

\begin{tabular}{lll}
\hline \multicolumn{1}{c}{ Nilai } & & Kriteria \\
\hline $\mathrm{X} \geq \mathrm{Mi}+1.5 \mathrm{Sdi}$ & Sangat Baik & \\
$\mathrm{Mi}+0.5 \mathrm{Sdi} \leq \mathrm{X}<\mathrm{Mi}+1.5 \mathrm{Sdi}$ & Baik & \\
$\mathrm{Mi}-0.5 \mathrm{Sdi} \leq \mathrm{X}<\mathrm{Mi}+0.5 \mathrm{Sdi}$ & Sedang & \\
$\mathrm{Mi}-1.5 \mathrm{Sdi} \leq \mathrm{X}<\mathrm{Mi}-0.5 \mathrm{Sdi}$ & Kurang Baik & \\
$\mathrm{X}<\mathrm{Mi}-1.5 \mathrm{Sdi}$ & Tidak Baik & \\
\hline
\end{tabular}

(Nurkancana and Sunartana, 1992)

- Note:

$\mathrm{Mi}=1 / 2($ Score Max + Score Min $)$

$\mathrm{Sdi}=1 / 3(\mathrm{Mi})$

$\mathrm{Mi}=$ the Ideal Mean

Sdi $=$ the Standard of Deviation

$X=$ The Score of the teacher.

Data analysis can be explained as follows:

- First, Mi and Sdi are obtained by the formula

$\mathrm{Mi}=1 / 2($ Score Max + Score Min $)$

$\mathrm{Sdi}=1 / 3(\mathrm{Mi})$

Because the maximum value is 5 and the minimum value is 1 , then

$\mathrm{Mi}=1 / 2(70+14)$

$\mathrm{Mi}=1 / 2(84)$

$\mathrm{Mi}=42$

and Sdi:

Sdi $=1 / 3(42)$

Sdi $=14$

- After Mi = 42 and $\mathrm{Sdi}=14$ are obtained, the product quality criteria to developed is shown as follows:

Table 2. Assessment Score Conversion

\begin{tabular}{ll}
\hline Value & Criteria \\
\hline$X \geq 63$ & Excellent \\
$49 \leq X<63$ & Good \\
$35 \leq X<49$ & Medium \\
$21 \leq X<35$ & Not so good \\
$X<21$ & Not good \\
\hline
\end{tabular}

The scores on the table above are then adjusted to the total score of each expert based on the checklist. The results can be seen in the following table. 
Table 3. Results of Expert Assessment on the Product

\begin{tabular}{lll}
\hline Expert & Scores & Rating \\
\hline Expert 1 & 64 & Excellent \\
Expert 2 & 63 & Excellent \\
\hline
\end{tabular}

Based on the validation of the results found by the experts, the quality of developed applications is categorized as excellent media. Although there are some weaknesses to be improved, the product developed in this study is expected to help Japanese language learners in facing the Japanese language skills test.

\section{Product Revision}

After testing is performed on this product, then in accordance with the input and suggestions provided by the two experts, revisions are then done in terms of the content and display of the media nouryoku shiken $\mathrm{N} 4$ with flash based mobile.

\section{Individual Test and Small Group Test Results}

The individual test involves 3 students while small group trials involve 9 students ( 3 high ability, 3 medium ability, 3 low ability). The results of the test were then converted based on the assessment conversion scores. The research results can be seen in table 4

Table 4 Individual Test Results

\begin{tabular}{lll}
\hline Expert & Scores & Rating \\
\hline Student 1 & 66 & Excellent \\
Student 2 & 64 & Excellent \\
Student 3 & 65 & Excellent \\
\hline
\end{tabular}

Table 5 Small Group Test Results

\begin{tabular}{lll}
\hline Expert & Scores & Rating \\
\hline Students with High Ability & & \\
Student 1 & 61 & Good \\
Student 2 & 65 & Excellent \\
Student 3 & 67 & Excellent \\
Students with Medium Ability & & \\
Student 4 & 66 & Excellent \\
Student 5 & 64 & Excellent \\
Student 6 & 60 & Good \\
Students with Low Ability & & \\
Student 7 & 59 & Good \\
Student 8 & 64 & Excellent \\
Student 9 & 66 & Excellent \\
\hline
\end{tabular}

Based on the validation of the individual test results, the quality of the developed application is categorized as excellent media. Meanwhile, based on the validation of small group test results, the quality of the applications developed is categorized as a Excellent and good media.

\section{CONCLUSION}


This research uses Hannafin and Peck's development model including 3 development phases, namely requirement analysis phase, design phase, and development and implementation phase. In the phase of requirement analysis, questioners were given to the second semester students of the Japanese Language Education Department, Ganesha Education University. In the design phase, material and product are designed, and then inputted into software. In the development and implementation phase, validation of the learning media is done by 2 experts, and then followed by individual test involving 3 students as well as small group test involving 9 students ( 3 high ability, 3 medium ability, 3 low ability). The data were then analyzed by qualitative descriptive analysis and quantitative descriptive analysis. Expert validation results show that the media is considered excellent, the validation of individual test results indicate that the media is considered excellent, and the validation of small group test results show that the media is considered good and excellent.

The results of this study are expected to facilitate the students who will take the test nouryoku shiken level 4 to learn and practice. In addition, this research is also expected to be useful for Japanese language teachers in facilitating the process of learning to teach basic level Japanese language. The significance of this research is that the developed application will be equipped with the material and optional package of practice questions that are varied and created according to the development of the tendency of vocabulary type and kanji letters that appear in Japanese language skills test. The results of this study are also expected to be useful as a reference in the study of the development of language learning application.

\section{REFERENCES}

Carqua, B. dan Sunneng S. B. (2015). Program Bantu Belajar Bahasa Jepang Standar Japanese Language Proficiency Test Level 5. In: Majalah Ilmiah Vol. 07, No. 02, Juli 2015. Retrieved October 3, 2017, from: http://www.ejurnal.ukrimuniversity.ac.id/file/Vol\%2007\%20No\%2002\%202015\%206\%20Sandino.pdf

Chandra, P. K., Sadyana, I. W., Antartika, I. K. (2017). Pengembangan Aplikasi Pembelajaran Kosa kata JLPT level 3 Berbasis Android untuk Mahasiswa Jurusan Pendidikan Bahasa Jepang Undiksha. In: Jurnal Jurusan Pendidikan Bahasa Jepang Vol 8 No 2. Retrieved October 2, 2017, from: https://ejournal.undiksha.ac.id/index.php/JJPBJ/article/view/10428

The Japan Foundation and Japan Educational Exchange. (2012). The Official Worldwide JapaneseLanguage Proficiency Test. Retrieved July 2, 2017, from:: http://www.jlpt.jp/e/

McPherson, Maggie and Miguel Baptista Nunes. (2004). Developing Innovation in Online Learning: an Action Research Framework. London: Routledge Falmer.

Pratomo, A. and Irawan, A. (2015). Pengembangan Media Pembelajaran Interaktif Berbasis Web Menggunakan Metode Hannafin dan Peck. In: Jurnal POSITIF, Tahun I, No. 1 November 2015: 14-28. Retrieved October 4, 2017, from: ejurnal.poliban.ac.id/index.php/Positif/article/view/204/201

Susilana, R. and Riyana, C. (2009). Media Pembelajaran: Hakikat, Pengembangan, Pemanfaatan, dan Penilaian. Bandung: CV Wacana Prima.

Wijaya, A. T. (2011). Media Pembelajaran Huruf Hiragana dan Katakana untuk Pemula Berbasis Multimedia Menggunakan Macromedia Flash. Program Studi Pendidikan Teknik Informatika, Fakultas Teknik, Universitas Negeri Yogyakarta. 